\title{
Mobilized Mohr-Coulomb and Hoek-Brown Strength Parameters during Failure of Granite in Alxa Area in China for High-Level Radioactive Waste Disposal
}

\author{
Cheng Cheng ${ }^{1, *}$, Nengxiong $\mathrm{Xu}^{1}$ and Bo Zheng ${ }^{2}$ \\ 1 School of Engineering and Technology, China University of Geosciences (Beijing), Beijing 100083, China; \\ xunengxiong@cugb.edu.cn \\ 2 Key Laboratory of Shale Gas and Geoengineering, Institute of Geology and Geophysics, \\ Chinese Academy of Sciences, Beijing 100029, China; zhengbo@mail.iggcas.ac.cn \\ * Correspondence: chengc@cugb.edu.cn; Tel.: +86-10-8232-2627
}

Received: 30 September 2019; Accepted: 30 October 2019; Published: 6 November 2019

\begin{abstract}
Strength parameters of the host rock is of paramount importance for modelling the behaviors of underground disposal repository of high-level radioactive waste (HLW). Mobilization of strength parameters should be studied for a better understanding and modelling on the mechanical behaviors of the surrounding rock, considering the effect of temperature induced by the nuclear waste. The granite samples cored from NRG01 borehole in Alxa candidate area in China for HLW disposal are treated by different temperatures $\left(\mathrm{T}=20^{\circ} \mathrm{C}, 100^{\circ} \mathrm{C}\right.$ and $\left.200^{\circ} \mathrm{C}\right)$, and then are used to carry out a series of uniaxial and tri-axial compression experiments under various confining pressures $\left(\sigma_{3}=0,5\right.$, 10,20 , and $30 \mathrm{MPa}$ ) in this study. With the recorded axial stress-axial strain and axial stress-lateral strain curves, mobilization of both Mohr-Coulomb and Hoek-Brown strength parameters are analyzed with the increasing plastic shear strain. It has been found that NRG01 granite samples show generally similar cohesion weakening and friction strengthening behaviors, as well as the non-simultaneous mobilization of Hoek-Brown strength parameters $\left(m_{\mathrm{b}}\right.$ and $\left.s\right)$, under the effect of various treatment temperatures. Furthermore, the samples treated by higher temperatures show lower initial values of cohesion, but their initial friction angle and $m_{\mathrm{b}}$ values are relatively higher. This should be mainly owing to the thermally induced cracks in the samples. This study should be helpful for a better modelling on the mechanical behaviors of NRG01 granite samples as the host rock of a possible HLW disposal repository.
\end{abstract}

Keywords: granite; HLW disposal; plastic strain; temperature; CWFS; damage process; yield condition; strength criterion

\section{Introduction}

Granite is considered as one of the most important types of host rock for geological disposal of high-level radioactive waste (HLW) [1-9]. An appropriate modelling on the mechanical behavior of granite is of great importance for site selection and design of the repository [9-13]. Specially, it should be noted that the heat induced by the nuclear waste may have considerable influences on the mechanical behavior of the host rock, so the thermal effect cannot be ignored $[8,12,14-17]$.

There have been extensive studies on the mechanical behaviors of the host rock for HLW disposal [1,9,18-22]. In many studies, simultaneously mobilized Mohr-Coulomb strength parameters (cohesion and friction angle) were used in the modelling of the underground excavation [23-27]. In order to describe the plastic strain softening behavior of the rock, they assumed that both cohesion and friction angle degrade from the initial value to the residual value with the increasing plastic strain, and piecewise linear models were usually adopted [23-27]. However, based on a series of 
theoretical analyses and laboratory experimental studies on cohesive soil, granite, marble, limestone, etc., it has been found that the geo-materials always show non-simultaneous mobilization of strength components, i.e., cohesion will be degraded and friction angle will be enhanced with the increasing damage or plastic strain during the failure process [26,28-35]. This is owing to the development of cracks inside the rock decreases the cohesive strength, while the induced crack surfaces make the frictional strength increases $[26,29,36]$. Accordingly, the cohesion weakening friction strengthening (CWFS) model was proposed, and this model with linear equations was used for modelling the failure process of URL Mine-by tunnel $[26,29,36]$. A comparison study shows that CWFS model can capture the failure extent and depth of failure (DOF) of this circular excavation better than the other widely used models such as elastic model, elastic-perfectly plastic model, elastic-brittle model, etc. [26]. Thereafter, more linear CWFS models are used in the researches and give reasonable simulations on the stability of underground openings, pillars, as well as the process of crack propagation [30,37-39]. Nonetheless, it was pointed out that the linear CWFS model may result in a problematic behavior of the stress - strain curves, and a fitted non-linear CWFS model with smooth curves was proposed, which was proved to be able to capture the gradual damage process better [31]. More recently, reference [40] proposed the guidelines for the parameters selection for CWFS modelling analysis of excavations. Up to date, the concept of CWFS analyses has widely been accepted in modelling the failure of brittle rocks.

However, the studies on the mobilization of strength parameters mainly focused on the Mohr-Coulomb criterion. As an actual fact, Hoek-Brown criterion is also widely used in the modelling of field rock engineering [41,42]. There were some studies using piecewise linear models with simultaneous mobilization of Hoek-Brown strength parameters ( $m$ and $s$ ) to analyze rock behaviors [23,24,26,43]. Nevertheless, according to the above-mentioned analyses on the non-simultaneous mobilization of cohesion and friction angle, we should notice whether the Hoek-Brown strength parameters may also be mobilized non-simultaneously during the damage and failure process of rock. If the answer is yes, what is the characteristics of this mobilization? What is the relationship between the mobilized Hoek-Brown strength parameters and the rock damage or plastic strain? This has not been investigated in the published researches, and it is required to conduct a detailed study.

In the recent several decades, extensive field and laboratory researches have been carried out in the site selection of HLW disposal in China [1,2,4,10,15,20,22,44,45]. Alxa candidate area in Inner Mongolia is one of the three candidate areas with large volume of granitic rock. Figure 1 presents the location of Alxa area with two sub-areas (TMS and NRG), as well as the main geological structures around this area. More detailed information about Alxa area has been provided in reference [1]. Field investigations on the outcrops have been conducted and four boreholes (named as TMS01, TMS02, NRG01 and NRG02) with the depth of $600 \mathrm{~m}$ have been drilled. Laboratory experiments on the cored samples have also been carried out for studying the mechanical properties of the rock. These researches show that the granite around NRG01 borehole shows the best rock mass quality in Alxa candidate area [1]. Nonetheless, further studies should still be conducted on NRG01 granite samples with coarse grains for a better modelling on the mechanical behaviors. What is the characteristics of the mobilization of cohesion and friction angle for NRG01 granite samples? How will the heat produced by the nuclear waste affect the mechanical behavior of NRG01 granite samples during the damage and failure process? Will the mobilization of Hoek-Brown strength parameters occur for NRG01 granite samples in a simultaneous or non-simultaneous way? Is there any suitable equations to describe this mobilization? What is the mechanism?

Based on a series of systematic uniaxial and tri-axial compression experiments on NRG01 granite samples treated by different temperatures, mobilization of both Mohr-Coulomb and Hoek-Brown strength parameters have been analyzed in details. This paper is organized as follows: In Section 2, the physical and mechanical properties of the samples, the experimental setup and methods will be introduced. The experimental results will be presented in Section 3. Section 4 will provide the systematic data analyses and discussions on both the mobilization of Mohr-Coulomb and Hoek-Brown strength 
parameters during the failure process of NRG01 granite samples under different heat treatments. Based on the above-mentioned analyses and discussions, some conclusions will be drawn in Section 5.

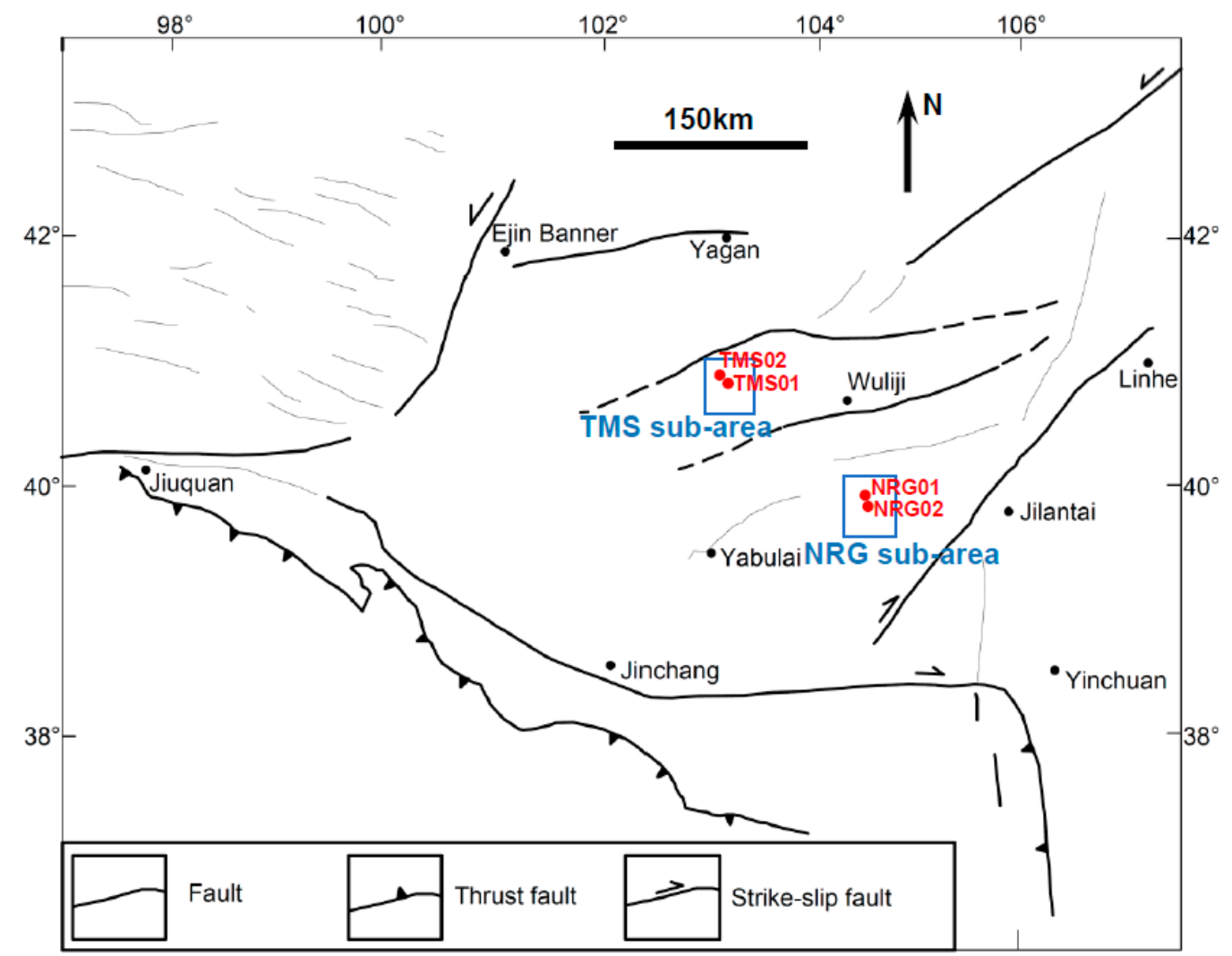

Figure 1. Schematic map of main geological structures around Alxa area. Modified after [46]. TMS01, TMS02, NRG01 and NRG02 are four boreholes drilled in TMS and NRG sub-areas.

\section{Samples and Experimental Methods}

NRG01 granite samples treated by different temperatures are used to conduct a series of uniaxial and tri-axial compression tests with various confining pressures. The obtained stress-strain data will be used for analyzing the mobilization of strength components during the brittle failure of granite considering the thermal effect.

\subsection{Samples}

The granite samples are cored from NRG01 borehole, which is one of the four $600 \mathrm{~m}$-deep boreholes in Alxa area. According to the field investigations on the corresponding outcrops, RQD analyses on the drilling cores, as well as the mechanical experiments on the cored specimens in laboratory, NRG01 samples show the best structural and strength quality and thus are selected to be used for further studies [1].

The pink samples are cored from the depth of 500-600 m. The typical samples are presented in Figure 2a,b. It can be found that the samples are heterogeneous and have coarse particles. According to the observation on thin sections under polarized microscopy, the mineral contents and the grain sizes of NRG01 granite samples are analyzed and listed in Table 1 [47]. Based on the mineral components, the samples should be named as biotite syenogranite. Nevertheless, they are still called as granite samples in this paper for simplicity. Figure $2 \mathrm{c}$ shows a comparison on the strength values of different granite samples under various confining pressures. Apparently, NRG01 samples have higher strength than TMS01 granite samples cored from TMS01 borehole in TMS sub-area (shown in Figure 1) of Alxa candidate area. Compared with BS06 granite samples cored from Beishan candidate 
area in Gansu Province [48], NRG01 samples show a little lower strength under lower confinements $\left(\sigma_{3}=0-10 \mathrm{MPa}\right)$, while a little higher strength under higher confinements $\left(\sigma_{3}>10 \mathrm{MPa}\right)$. Based on peak strength values fitted with linear Mohr-Coulomb criterion, NRG01 granite samples have the cohesion of $20.1 \mathrm{MPa}$, and internal friction angle of $57.5^{\circ}$. Hoek-Brown criterion is also used to analyze the data, and the non-linear Hoek-Brown fitting curve is shown in Figure 2c.

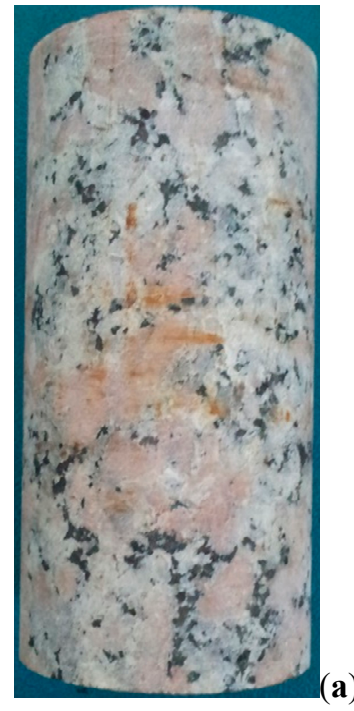

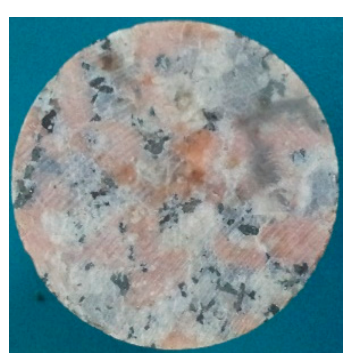

(b)

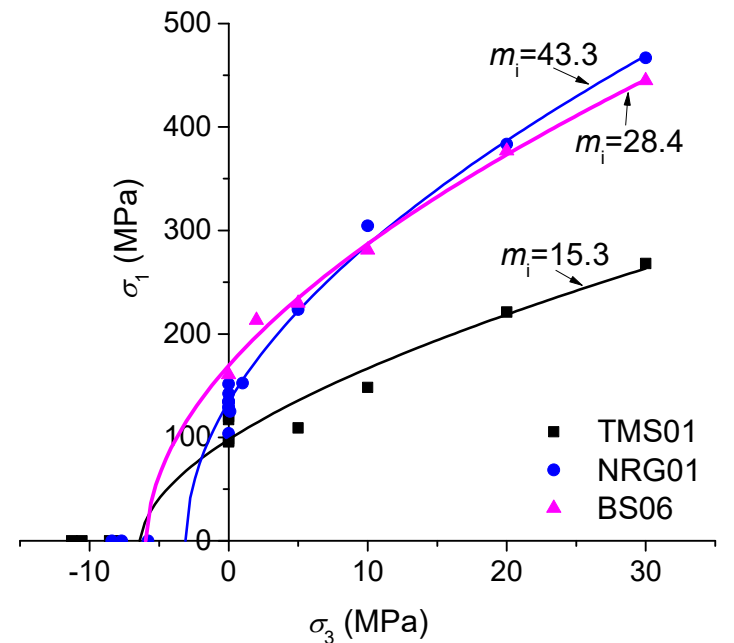

(c)

Figure 2. (a,b) Typical NRG01 granite samples (Height: 100mm; Diameter: 50mm) [1] and (c) strength of NRG01 granite under various confinements comparing with TMS01 granite as well as BS06 granite from Beishan area, Gansu Province [48].

Table 1. Mineral contents and grain sizes of NRG01 granite samples (based on [47]).

\begin{tabular}{ccc}
\hline Minerals & Contents & Grain Sizes $(\mathbf{m m})$ \\
\hline alkali feldspar & $45 \%$ & $2.0-8.0$ \\
plagioclase & $18 \%$ & $1.3-3.0$ \\
quartz & $25 \%$ & $1.5-4.0$ \\
biotite & $12 \%$ & $0.8-1.5$ \\
\hline
\end{tabular}

\subsection{Experimental Methods}

A series of cylindrical NRG01 granite samples are well prepared (listed in Table 2) for uniaxial and tri-axial compression experiments under various confining pressures $\left(\sigma_{3}=0,5,10,20\right.$, and $\left.30 \mathrm{MPa}\right)$. Concerning the heat produced by the high-level radioactive waste during the long-term disposal period, the effect of temperature should also be considered in this study. According to an extensive review on the conceptual design of repositories [7,49-52], the temperature applied on the host rock will be no higher than $100^{\circ} \mathrm{C}-120^{\circ} \mathrm{C}$. Consequently, this study focuses on the range from $20^{\circ} \mathrm{C}$ (room temperature) to $200^{\circ} \mathrm{C}$.

The specimens are firstly heated in a heating cabinet to the designed temperatures as shown in Table 2. The heating rate is set as $2{ }^{\circ} \mathrm{C} / \mathrm{min}$. When the target temperatures are reached, the heat treated samples are used for a series of uniaxial and tri-axial compression experiments with the TAW2000 servo-control tri-axial compression test system in Key Laboratory of Shale Gas and Geoengineeirng, Chinese Academy of Sciences. It should be noted that the rock specimens cannot remain their treatment temperatures as there is not a heating system during the compression tests. The confining pressures are applied to the target values as presented in Table 2, followed by the axial loading at a constant strain rate of $1.0 \times 10^{-5} \cdot \mathrm{s}^{-1}$. During each test, the axial and lateral strain are both measured with a set of extensometers, and the axial stress is obtained according to the axial load monitored by a force sensor. Consequently, the axial stress - axial strain curve and axial stress-lateral strain curve can be 
recorded for each test, and the failure characteristics of the specimens will also be observed after the experiments are completed.

Table 2. Design for the tests under different confinements and heat treatment.

\begin{tabular}{cccccc}
\hline NO. & Length $(\mathbf{m m})$ & Diameter $(\mathbf{m m})$ & Density $\mathbf{( g / \mathbf { m m } ^ { 3 } )}$ & Confinement $\mathbf{M P a})$ & Temperature $\left({ }^{\circ} \mathbf{C}\right)$ \\
\hline N1-20 & 100.17 & 49.55 & 2.64 & 0 & 20 \\
N1-14 & 100.13 & 49.51 & 2.65 & 5 & 20 \\
N1-29 & 99.67 & 49.99 & 2.63 & 10 & 20 \\
N1-7 & 100.31 & 49.99 & 2.65 & 20 & 20 \\
N1-23 & 100.09 & 49.46 & 2.64 & 5 & 20 \\
N1-77 & 100.39 & 50.17 & 2.63 & 0 & 100 \\
N1-83 & 100.32 & 50.03 & 2.63 & 5 & 100 \\
N1-85 & 100.15 & 50.02 & 2.65 & 10 & 100 \\
N1-88 & 100.28 & 50.14 & 2.64 & 20 & 100 \\
N1-92 & 100.45 & 50.11 & 2.64 & 30 & 200 \\
N1-79 & 100.49 & 50.21 & 2.65 & 0 & 200 \\
N1-82 & 100.32 & 49.74 & 2.64 & 5 & 200 \\
N1-87 & 100.37 & 50.13 & 2.63 & 10 & 200 \\
N1-89 & 100.45 & 49.72 & 2.64 & 20 & 200 \\
N1-93 & 98.79 & 50.14 & 2.65 & 30 & \\
\hline
\end{tabular}

\section{Experimental Results}

The differential stress - axial strain curves and differential stress-lateral strain curves for all the tests are presented in Figure $3 a-e$. It should be noted that differential stress $\left(\sigma_{1}-\sigma_{3}\right)$ is used in these curves in order for a more consistent observation. The peak strength values and the strength envelopes fitted with Hoek-Brown criterion are shown in Figure 3f. Based on these test results, some features can be observed as follows:

(1) For the NRG01 granite samples treated by different temperatures $\left(\mathrm{T}=20^{\circ} \mathrm{C}, 100{ }^{\circ} \mathrm{C}\right.$ and $\left.200{ }^{\circ} \mathrm{C}\right)$, the differential stress - axial strain curves show the similar brittle - ductile transition behaviors with the increasing confining pressures $\left(\sigma_{3}=0-30 \mathrm{MPa}\right)$;

(2) According to the experimental results, the heat treatment by temperatures no higher than $200{ }^{\circ} \mathrm{C}$ does not have very significant influence on the stress - strain curves of the NRG01 granite samples under various confining pressures $\left(\sigma_{3}=0-30 \mathrm{MPa}\right)$. However, if we make a more careful observation, it can be found that the samples treated by higher temperature show relatively more ductile behavior during the post-peak stage;

(3) The peak strength values are also very close for the samples treated by different temperatures. This means that the heat treatment by temperatures no higher than $200{ }^{\circ} \mathrm{C}$ does not have very obvious influence on the strength values of the NRG01 granite samples under various confining pressures $\left(\sigma_{3}=0-30 \mathrm{MPa}\right)$.

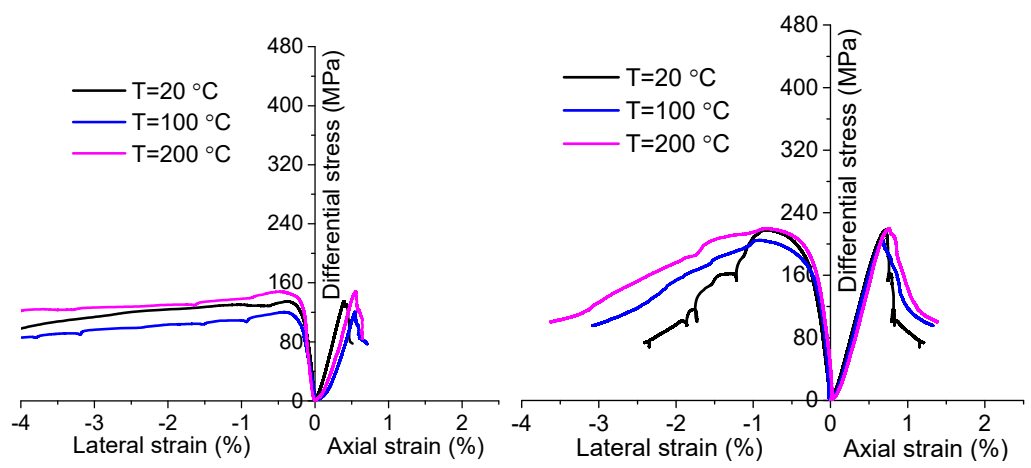

(a)

(b)

Figure 3. Cont. 


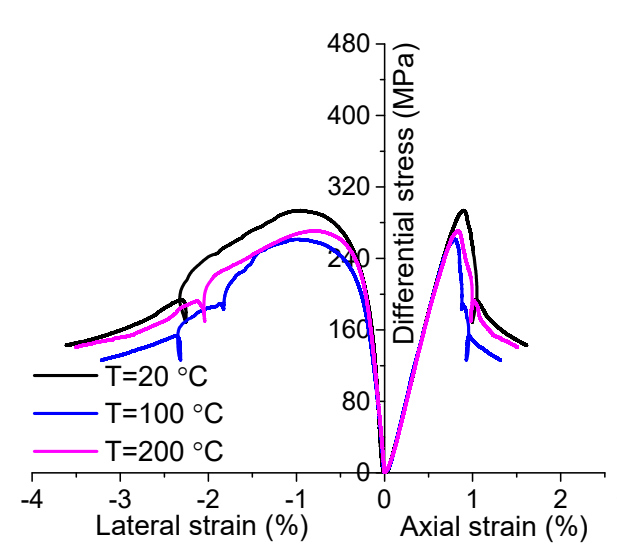

(c)

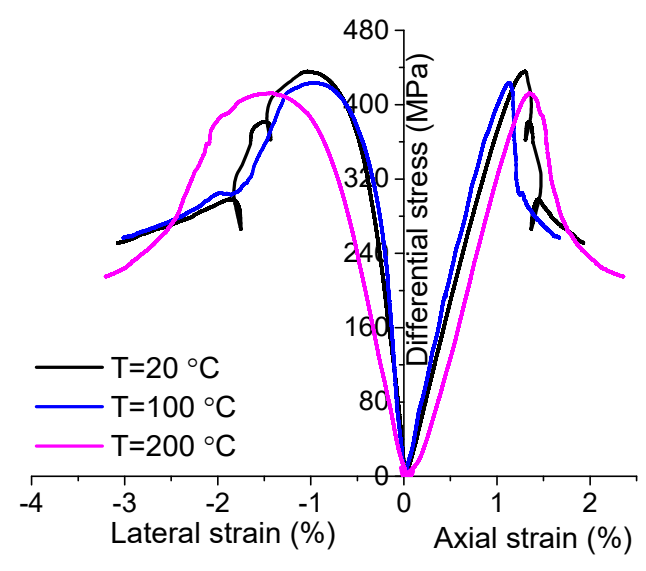

(e)

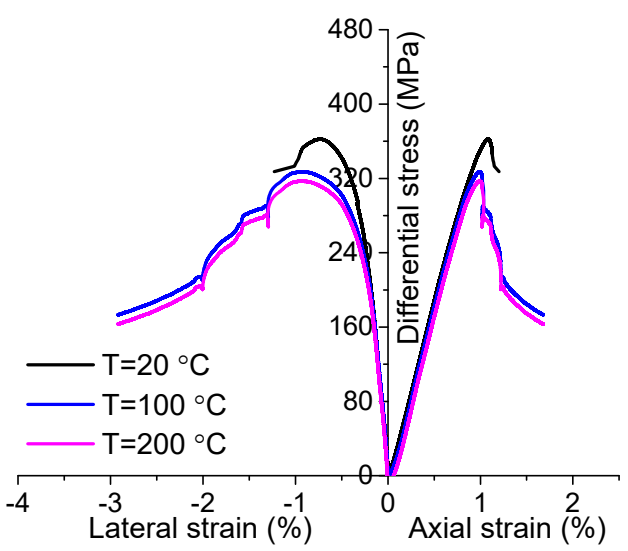

(d)

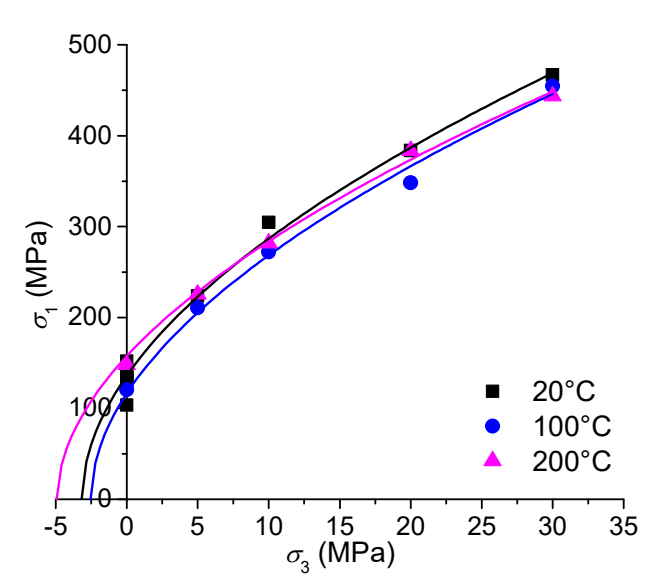

(f)

Figure 3. Differential stress-axial strain and differential stress-lateral strain curves of NRG01 granite samples treated by various temperatures under the confinement of (a) $0 \mathrm{MPa}$, (b) $5 \mathrm{MPa}$, (c) $10 \mathrm{MPa}$, (d) $20 \mathrm{MPa}$, (e) $30 \mathrm{MPa}$; and (f) the fitted peak strength envelops.

\section{Data Analyses and Discussion}

\subsection{Mobilized Mohr-Coulomb Strength Parameters During Failure of NRG01 Granite}

\subsubsection{Analytical Method}

According to the previous studies [26,28,31,33,53], the Mohr-Coulomb strength parameters (cohesion $c$ and inner frictional angle $\varphi$ ) of rock should be mobilized dependent on rock damage or plastic parameters of geo-materials. The most widely accepted plastic parameter is the plastic shear strain $\gamma^{\mathrm{p}}$, which can be obtained as the difference between the maximum and minimum principal plastic strains ( $\varepsilon_{1}^{\mathrm{p}}$ and $\varepsilon_{3}^{\mathrm{p}}$, respectively) $[27,30,33,54]$ :

$$
\gamma^{\mathrm{p}}=\varepsilon_{1}^{\mathrm{p}}-\varepsilon_{3}^{\mathrm{p}}
$$

There are usually two methods to obtain the plastic strain values. One method is to differentiate the recoverable and irrecoverable strain by taking cyclic loading-unloading experiments. The plastic strain can be obtained from the irrecoverable strain in each cycle of the tests directly, however, it is quite complicated to control this type of experiment, and the data is limited by the numbers of cycles $[27,33,54,55]$. Therefore, another method is developed based on the assumption that the 
unloading curve in each cycle has the same modulus as the initial deformation modulus. In this way, a series of plastic strains can be obtained with a series of assumed loading-unloading cycles by just carrying out conventional uniaxial and tri-axial compression experiments. This method has been widely accepted and used in many studies $[27,33,54]$ and is also employed here in this research. Figure 4 gives a sketch to illustrate this method for determining the plastic axial and lateral strains, as well as the corresponding axial stress values. A series of lines parallel with the tangent lines at the linear elastic stage of the $\sigma_{1}-\varepsilon_{1}$ curves are drawn to determine the plastic axial strain $\varepsilon_{1, i}^{\mathrm{p}}$ and plastic lateral strain $\varepsilon_{3, i^{\prime}}^{\mathrm{p}}$ respectively. The symbol $i$ here is a series of positive integers, showing that a series of plastic strain values can be collected with this method. It should be noted that there is a gap $|O A|$ owing to the crack closure stage of $\sigma_{1^{-1}}$ curves, so this gap should be removed for determining the plastic axial strain $\varepsilon_{1, i}^{\mathrm{p}}$ :

$$
\varepsilon_{1, i}^{\mathrm{p}}=|O B|-|O A|, \quad \varepsilon_{1, i+1}^{\mathrm{p}}=|O C|-|O A|,
$$

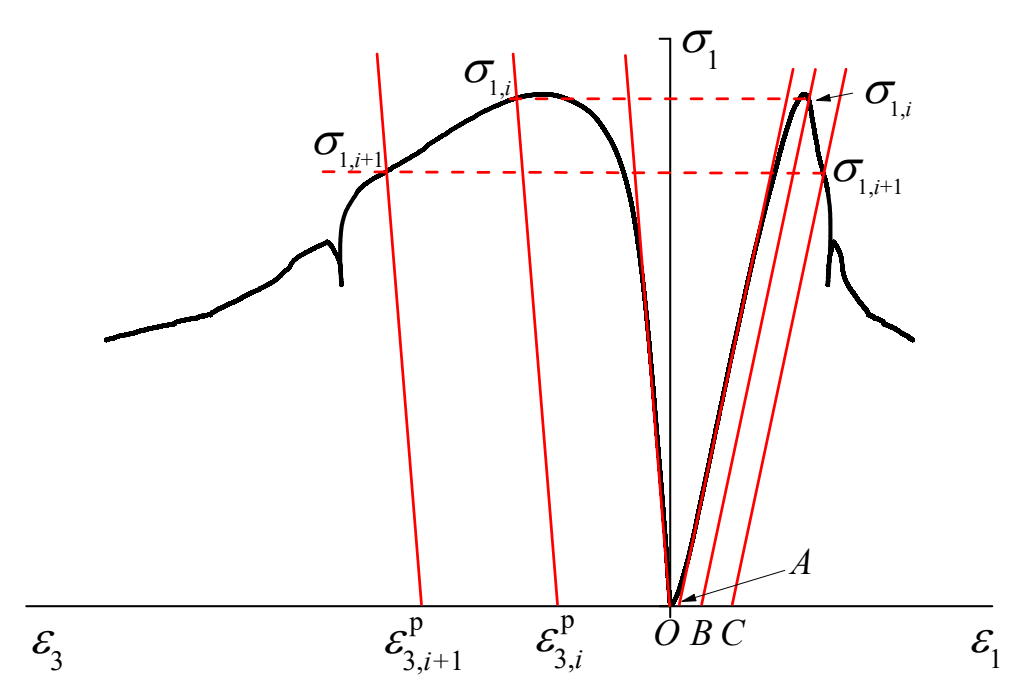

Figure 4. Sketch of the method for determining plastic strains and the corresponding stress values.

Then the plastic shear strain can be obtained as:

$$
\gamma_{i}^{\mathrm{p}}=\varepsilon_{1, i}^{\mathrm{p}}-\varepsilon_{3, i^{\prime}}^{\mathrm{p}}
$$

For each plastic shear strain, the corresponding maximum principal stress $\sigma_{1}$ is collected under different confining pressures $\sigma_{3}$. Thereafter, cohesion $c$ and internal friction angle $\varphi$ can be calculated by drawing Mohr circles or by linear fitting of $\sigma_{1}$ and $\sigma_{3}$ with the following equation:

$$
\sigma_{1}=\frac{2 c \cos \varphi}{1-\sin \varphi}+\frac{1+\sin \varphi}{1-\sin \varphi} \sigma_{3}
$$

The values of $c$ and $\varphi$ can then be plotted with the increasing plastic shear strain. As the temperature induced by the high-level radioactive waste may affect the mechanical behavior of the host rock, the evolutionary characteristics of $c$ and $\varphi$ are also studied for NRG01 granite under different heat treatment $\left(20^{\circ} \mathrm{C}-200^{\circ} \mathrm{C}\right)$.

\subsubsection{Data Analyses and Discussion}

Based on the stress-strain curves of NRG01 granite under different heat treatment and confinements presented in Figure 3, as well as the methodology demonstrated in Section 4.1.1, a series of axial stress at different plastic shear strains can be plotted in Figure 5. For each plastic shear strain, a set of axial 
stress values under various confining pressures can be obtained to calculate the cohesion and friction angle. These values are shown in Figure 5.

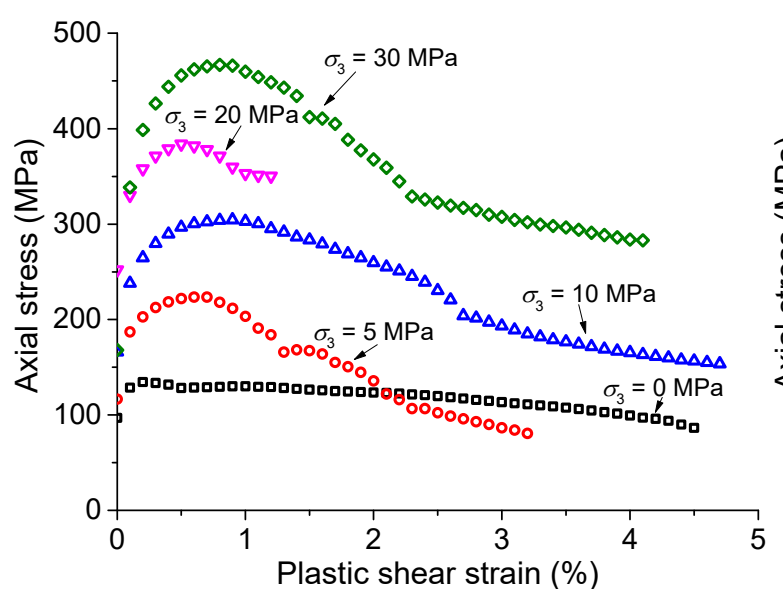

(a)

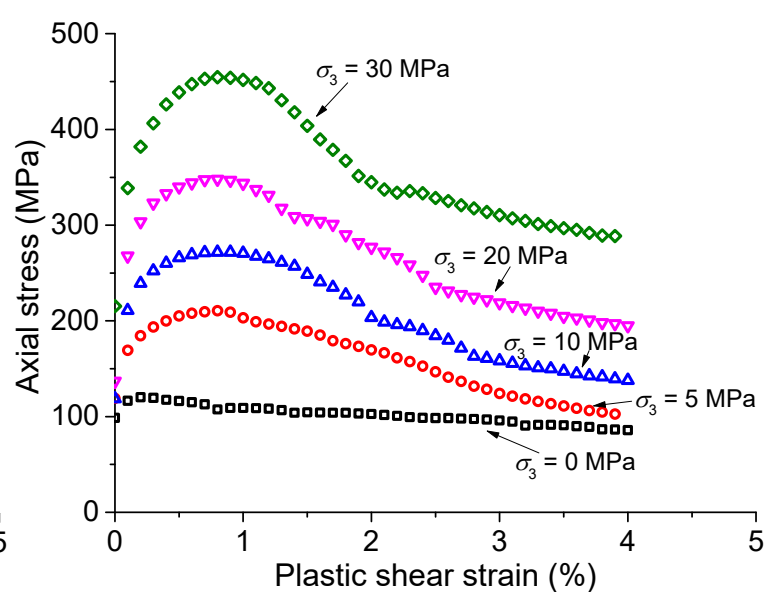

(b)

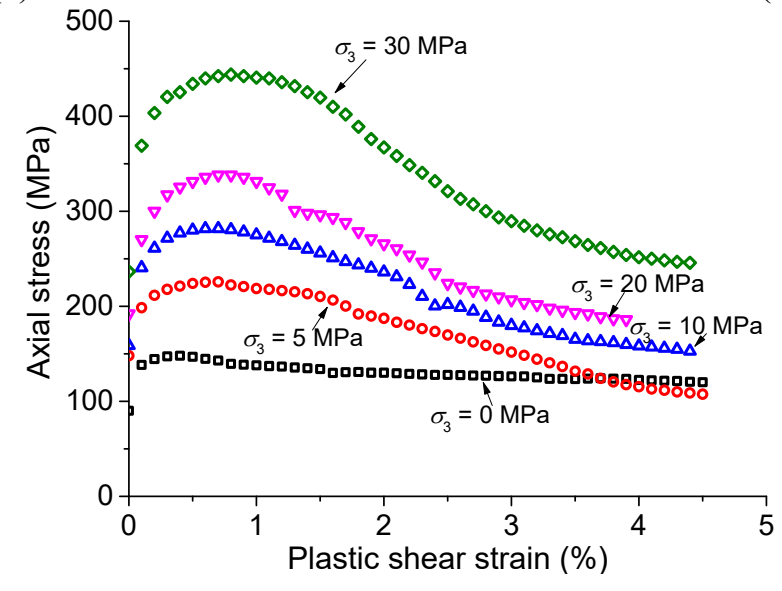

(c)

Figure 5. Evolution of maximum principal stresses of NRG01 granite samples treated by different temperatures: (a) $\mathrm{T}=20^{\circ} \mathrm{C}$; (b) $\mathrm{T}=100^{\circ} \mathrm{C}$ and (c) $\mathrm{T}=200^{\circ} \mathrm{C}$.

The results obtained in Figure 6 show that NRG01 granite samples have the generally cohesion weakening and friction strengthening (CWFS) behaviors for various treatment temperatures (room temperature to $200^{\circ} \mathrm{C}$ ). According to the published references $[26,29,31,36]$, the cohesion component should be weakened to the residual value before the full mobilization of friction angle, however, it is not true for NRG01 granite treated by different temperatures. It is shown that cohesion is weakened in a gradual manner with increasing plastic shear strain, nevertheless, the friction angle increases to the peak value more immediately. As an actual fact, the test results similar to this study can also be found in references $[30,31,33]$. This difference has also been discussed in $[29,36]$, and it is believed that the plastic strain limit at which the cohesion reaches the residual value or the friction angle is fully mobilized is dependent on many factors such as the rock type, grain size, heterogeneity, as well as the hoop effect owing to the cylindrical shape of the specimens, etc. More systematic studies should be carried out to learn more clearly about the exact influencing factors and the mechanism. 


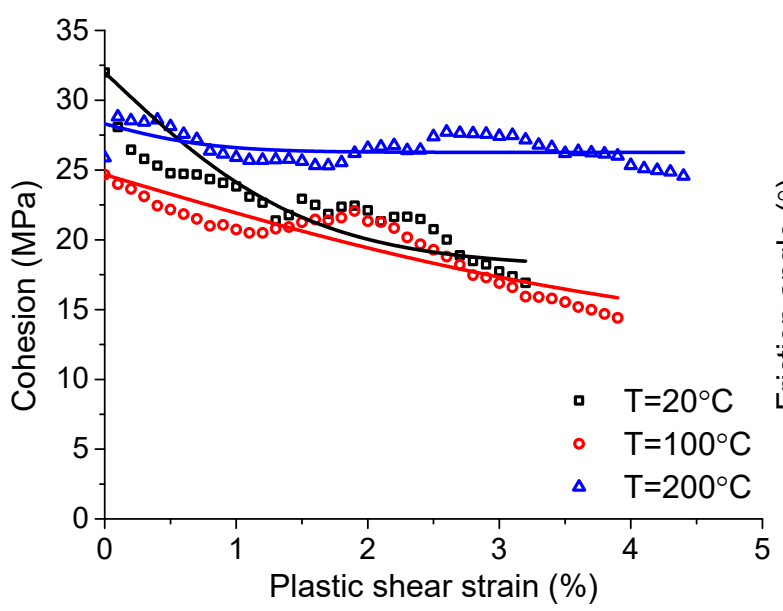

(a)

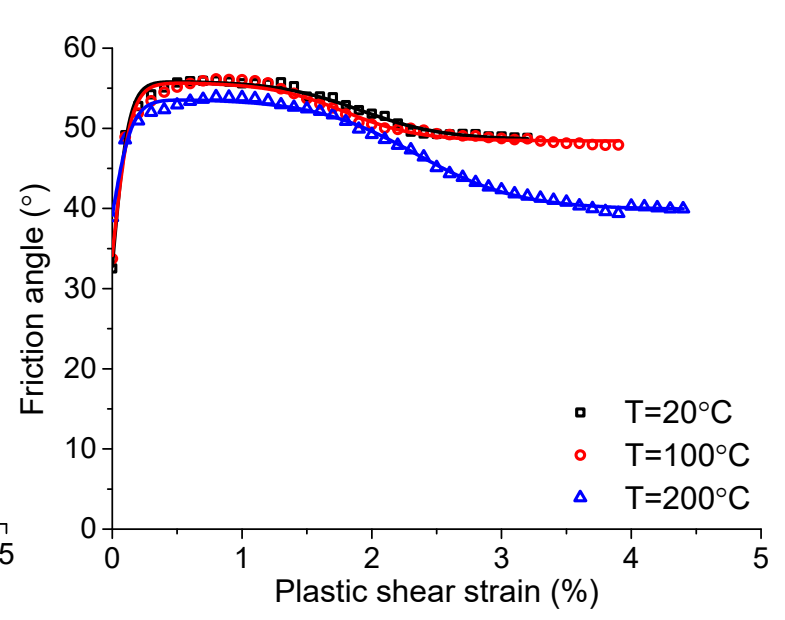

(b)

Figure 6. Mobilized (a) cohesion and (b) friction angle of NRG01 granite samples treated by different temperatures.

Based on the characteristics of the mobilized cohesion and friction angle presented in Figure 6, the generally used linear CWFS model [30,37-39] may not be suitable for NRG01 granite. For a better description of the rock behaviors, a non-linear model should be used. With the fitting Equations (5) and (6) proposed in reference [31], the mobilized cohesion and friction angle values can be well fitted as shown in Figure 6. The fitted coefficients are listed in Table 3.

$$
c=c_{\mathrm{r}}+\left(c_{\mathrm{i}}-c_{\mathrm{r}}\right)\left[2-\frac{2}{1+\exp \left(-5 \frac{\gamma^{\mathrm{p}}}{\gamma_{c, \mathrm{r}}^{\mathrm{p}}}\right)}\right],
$$

where, $c_{\mathrm{i}}$ and $c_{\mathrm{r}}$ are the initial and residual values of cohesion, respectively. $\gamma_{c, \mathrm{r}}^{\mathrm{p}}$ is the plastic shear strain when the cohesion is close to the residual value.

$$
\varphi=\varphi_{\mathrm{i}}+\left(\varphi_{\max }-\varphi_{\mathrm{i}}\right)\left[\frac{2}{1+\exp \left(-5 \frac{\gamma^{\mathrm{p}}}{\gamma_{\varphi, \max }^{\mathrm{p}}}\right)}-1\right]-\left(\varphi_{\max }-\varphi_{\mathrm{r}}\right)\left[\frac{1}{1+\exp \left(-5 \frac{2 \gamma^{\mathrm{p}}-\gamma_{\varphi, \mathrm{r}}^{\mathrm{p}}}{\gamma_{\varphi, \mathrm{r}}^{\mathrm{p}}}\right)}\right],
$$

where, $\varphi_{\mathrm{i}}$ is the initial value of friction angle, while $\varphi_{\max }$ is the maximum value, and $\varphi_{\mathrm{r}}$ is the residual value. $\gamma_{\varphi, \max }^{\mathrm{p}}$ is the plastic shear strain when the friction angle is close to its peak value, while $\gamma_{\varphi, \mathrm{r}}^{\mathrm{p}}$ is the plastic shear strain when the friction angle is close to its residual value.

Table 3. The fitted coefficients determining the mobilized Mohr-Coulomb strength parameters during the failure of NRG01 granite samples under different treatment temperatures.

\begin{tabular}{ccccccccccc}
\hline Temperature $\left({ }^{\circ} \mathbf{C}\right)$ & $c_{\mathbf{i}}$ & $c_{\mathbf{r}}$ & $\gamma_{c, \mathbf{r}}^{\mathbf{p}}$ & $R^{2}$ & $\varphi_{\mathbf{i}}$ & $\varphi_{\max }$ & $\varphi_{\mathbf{r}}$ & $\gamma_{\varphi, \max }^{\mathbf{p}}$ & $\gamma_{\varphi, \mathbf{r}}^{\mathbf{p}}$ & $R^{2}$ \\
\hline 20 & 31.99 & 18.00 & 3.93 & 0.6696 & 32.78 & 55.91 & 48.58 & 0.31 & 3.52 & 0.9864 \\
100 & 24.67 & 12.00 & 11.35 & 0.8341 & 34.14 & 55.74 & 48.43 & 0.35 & 3.23 & 0.9746 \\
200 & 28.31 & 26.26 & 2.08 & 0.2001 & 39.21 & 53.70 & 39.89 & 0.38 & 4.3 & 0.9931 \\
\hline
\end{tabular}

According to Figure 6, it can also be observed that the different treated temperatures may lead to a few different evolutionary behaviors of cohesion and friction angle for NRG01 granite samples. The more obvious influences are shown for the behaviors of cohesion component, i.e., the sample under room temperature $\left(\mathrm{T}=20^{\circ} \mathrm{C}\right)$ shows an apparently higher initial cohesion value $(c=31.99 \mathrm{MPa})$, and a 
more obvious decrease with the increasing plastic shear strain, compared with the samples treated by higher temperatures ( $c=24.67 \mathrm{MPa}$ and $25.88 \mathrm{MPa}$ for $\mathrm{T}=100^{\circ} \mathrm{C}$ and $200{ }^{\circ} \mathrm{C}$, respectively). This should be explained by the more thermally induced cracks in the heat treated samples, which decreased the initial cohesive strength of the specimens. According to Figure $6 \mathrm{~b}$, the thermally treated samples by higher temperatures present higher initial friction angles $\left(\varphi=38.87^{\circ}\right.$ for $\mathrm{T}=200^{\circ} \mathrm{C}$, compared with $\varphi$ $=32.54^{\circ}$ and $33.74^{\circ}$ for $\mathrm{T}=20^{\circ} \mathrm{C}$ and $100^{\circ} \mathrm{C}$, respectively), which should also be resulted from the more thermally induced crack surfaces treated by higher temperatures. Based on these observations, a general trend can be concluded that higher treatment temperatures may lead to relatively lower initial values of cohesion $(c)$ and higher initial values of friction angles $(\varphi)$ for NRG01 granite samples. This phenomenon should be owing to the different amounts of thermally induced cracks inside the rock under the effects of different temperatures.

This section demonstrates the characteristics of mobilized cohesion and friction angle during the failure process of NRG01 granite samples treated by different temperatures. The non-simultaneous mobilization should be considered in the constitutive models when analyzing the stability of the host rock for site selection or design of a HLW disposal repository.

\subsection{Mobilized Hoek-Brown Strength Parameters During Failure of NRG01 Granite}

As discussed above, the non-simultaneous mobilization of strength parameters mainly focused on the linear Mohr-Coulomb criterion. For the widely used non-linear Hoek-Brown criterion, only simultaneous mobilization of strength parameters ( $m$ and $s$ ) can be found to be considered in the published studies [23-26]. It is quite necessary to research the mobilization behaviors of Hoek-Brown strength parameters during the failure process of rock. This section will present such a study based on the laboratory experiments on NRG01 granite samples treated by different temperatures.

\subsubsection{Analytical Method}

The similar method as illustrated in Figure 4 is used here for determining a series of plastic strain and axial stress values. So the same results presented in Figure 5 can be used in this part of analyses. For each certain plastic shear strain value, the set of stress values under different confining pressures are used to fit the Hoek-Brown criterion [26,42]:

$$
\sigma_{1}=\sigma_{3}+\sigma_{\mathrm{ci}}\left(m_{\mathrm{b}} \frac{\sigma_{3}}{\sigma_{\mathrm{ci}}}+s\right)^{a}
$$

where, $\sigma_{1}$ and $\sigma_{3}$ are the maximum and minimum principal stresses, respectively; $\sigma_{\mathrm{ci}}$ is the uniaxial compression strength of the intact rock; $m_{\mathrm{b}}, s$ and $a$ are the constants for the damaged rock specimens.

It should be noted that the parameter $s$ is related to the fracturing degree of the samples. When $\sigma_{3}=0$, the uniaxial compression strength of the damaged samples can be obtained as:

$$
\sigma_{\mathrm{c}}=\sigma_{\mathrm{ci}} a^{a}
$$

As the constant $a$ is defined as:

$$
a=\frac{1}{2}+\frac{1}{6}\left(e^{-G S I / 15}-e^{-20 / 3}\right)
$$

where, GSI is the Geological Strength Index indicating the rock quality with the number ranging from 0 (totally fractured) to 100 (intact) [41,42]. It can be seen that for $25<G S I<100$, the value of $a$ is very close to 0.5 . Therefore, $a$ is reasonable enough to be set as a constant number 0.5 for simplicity in this study. Thereafter, for the damaged samples at each plastic shear strain, $s$ can be identified based on the corresponding uniaxial compression strength values presented in Figure 5 by the following equation:

$$
s=\left(\sigma_{\mathrm{c}} / \sigma_{\mathrm{ci}}\right)^{0.5}
$$


With the determined $s$ values, a series of $m_{\mathrm{b}}$ values can be obtained by fitting the data in Figure 5 with Equation (7). As a result, the mobilized $m_{\mathrm{b}}$ and $s$ values varying with plastic shear strain for NRG01 granite samples treated by different temperatures are presented in Figure 7a,b, respectively.

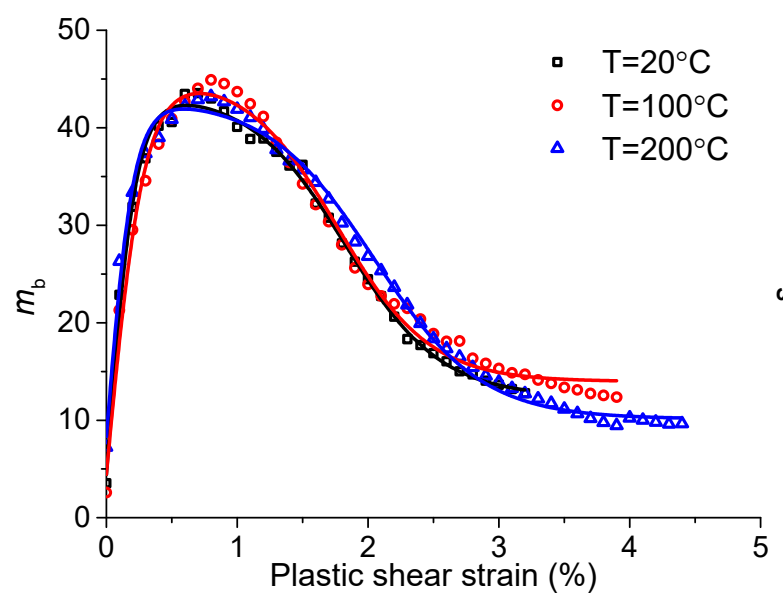

(a)

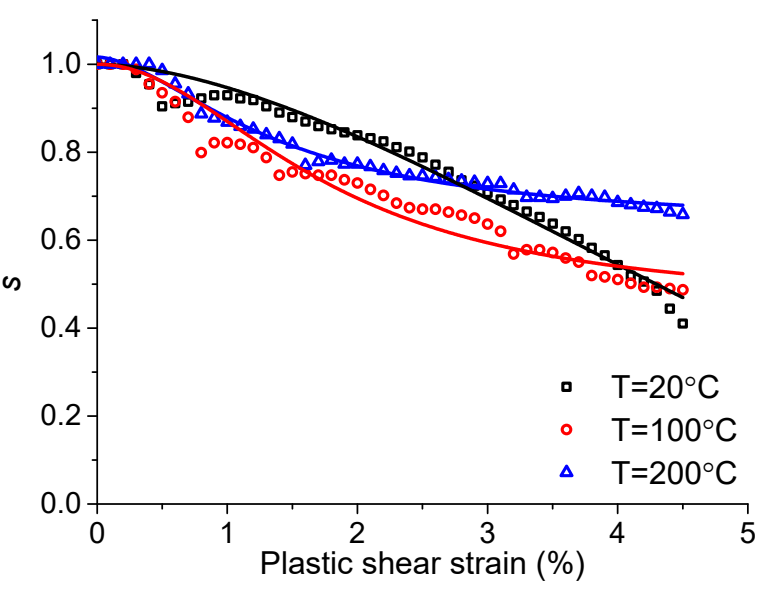

(b)

Figure 7. Mobilized Hoek-Brown strength parameters (a) $m_{\mathbf{b}}$ and (b) $s$ of NRG01 granite treated by different temperatures: $\mathrm{T}=20^{\circ} \mathrm{C}, \mathrm{T}=100^{\circ} \mathrm{C}$ and $\mathrm{T}=200^{\circ} \mathrm{C}$.

\subsubsection{Data Analyses and Discussion}

According to Figure 7, for NRG01 granite samples treated by different temperatures $\left(\mathrm{T}=20^{\circ} \mathrm{C}\right.$, $100{ }^{\circ} \mathrm{C}$ and $\left.200^{\circ} \mathrm{C}\right)$, several features can be observed as follows:

(1) Similar to the mobilization of cohesion and friction angle, the mobilization of Hoek-Brown strength parameters $\left(m_{\mathrm{b}}\right.$ and $\left.s\right)$ is also non-simultaneous during the failure process of NRG01 granite treated by different temperatures no higher than $200^{\circ} \mathrm{C}$;

(2) With increasing plastic shear strain, $m_{\mathrm{b}}$ increases significantly to a maximum value and then decreases until a residual value;

(3) $s$ decreases gradually with the increasing plastic shear strain. This is related to the damage and fracturing process during the tests.

The mobilization of $m_{\mathrm{b}}$ can be fitted with Equation (11):

$$
\begin{aligned}
m_{\mathrm{b}}=m_{\mathrm{bi}}+\left(m_{\mathrm{bmax}}\right. & \left.-m_{\mathrm{bi}}\right)\left[\frac{2}{1+\exp \left(-5 \frac{\gamma^{\mathrm{p}}}{\gamma_{\mathrm{mb}, \max }}\right)}-1\right] \\
& -\left(m_{\mathrm{bmax}}-m_{\mathrm{br}}\right)\left[\frac{1}{1+\exp \left(-5 \frac{2 \gamma^{\mathrm{p}}-\gamma_{m \mathrm{~b}, \mathrm{r}}^{\mathrm{p}}}{\gamma_{m \mathrm{~b}, \mathrm{r}}^{\mathrm{r}}}\right)}\right],
\end{aligned}
$$

where, $m_{\mathrm{bi}}$ and $m_{\mathrm{br}}$ are the initial and residual value of $m_{\mathrm{b}}$, respectively; $m_{\mathrm{bmax}}$ is the maximum value of $m_{\mathrm{b}} ; \gamma_{m \mathrm{~b}, \max }^{\mathrm{p}}$ is the plastic shear strain when $m_{\mathrm{b}}$ is close to its peak value, while $\gamma_{m \mathrm{~b}, \mathrm{r}}^{\mathrm{p}}$ is the plastic shear strain when $m_{\mathrm{b}}$ is close to its residual value.

The mobilization of $s$ can be fitted with Equation (12):

$$
s=\frac{s_{\mathrm{i}}-s_{\mathrm{r}}}{1+\left(\gamma^{\mathrm{p}} / \gamma_{0}^{\mathrm{p}}\right)^{n}}+s_{\mathrm{r}}
$$


where, $s_{\mathrm{i}}$ and $s_{\mathrm{r}}$ are the initial and residual value of $s$, respectively. $\gamma_{0}^{\mathrm{p}}$ is the transitional plastic shear strain when the $s$ value turns to decrease in a gradual manner. $n$ is a constant determining the shape of the curve.

The fitted curves are presented in Figure 7, and the fitted coefficients are shown in Table 4. According to Figure $7 \mathrm{a}$, it can be observed that the mobilization of $m_{\mathrm{b}}$ value has very similar characteristics with the increasing plastic shear strain, for the NRG01 granite samples treated by different temperatures $\left(\mathrm{T}=20^{\circ} \mathrm{C}, 100^{\circ} \mathrm{C}\right.$ and $\left.200^{\circ} \mathrm{C}\right)$. Based on a more detailed observation on Figure $7 \mathrm{a}$, we can find that for the NRG01 granite samples treated by the temperature $\mathrm{T}=200{ }^{\circ} \mathrm{C}$, the initial value of $m_{\mathbf{b}}=7.24$. This is apparently higher than the value for the cases of lower temperatures $\left(m_{\mathbf{b}}=3.54\right.$ and 2.59 , for $\mathrm{T}=20^{\circ} \mathrm{C}$ and $100{ }^{\circ} \mathrm{C}$, respectively). It is always believed that $m_{\mathrm{b}}$ value is more related to the frictional strength in Mohr-Coulomb criterion [29,56]. For the case of $\mathrm{T}=200^{\circ} \mathrm{C}$, there should be more crack surfaces induced by the heat in the granite samples, and this should be the reason why the initial values of friction angle and $m_{\mathrm{b}}$ are both higher. According to Figure $7 \mathrm{~b}$, the mobilization of $s$ value are also quite similar with the increasing plastic shear strain, for the NRG01 granite samples treated by different temperatures $\left(\mathrm{T}=20^{\circ} \mathrm{C}, 100^{\circ} \mathrm{C}\right.$ and $\left.200^{\circ} \mathrm{C}\right)$. There are not enough evidence to prove how heat treatment influence the mobilization of $s$ value based on this study. More systematic experimental studies should be carried out in order to make clear the characteristics of mobilized $s$ during the failure process of granite treated by different temperatures.

Table 4. The fitted coefficients determining the mobilized Hoek-Brown strength parameters during the failure of NRG01 granite samples under different treatment temperatures.

\begin{tabular}{|c|c|c|c|c|c|c|c|c|c|c|c|}
\hline $\mathrm{T}\left({ }^{\circ} \mathrm{C}\right)^{1}$ & $m_{\mathrm{bi}}$ & $m_{\mathrm{br}}$ & $m_{\text {bmax }}$ & $\gamma_{m \mathrm{~b}, \max }^{\mathrm{p}}$ & $\gamma_{m \mathrm{~b}, \mathrm{r}}^{\mathrm{p}}$ & $R^{2}$ & $s_{\mathbf{i}}$ & $s_{\mathrm{r}}$ & $\gamma_{0}^{\mathbf{p}}$ & $n$ & $R^{2}$ \\
\hline 20 & 4.64 & 12.40 & 43.71 & 0.56 & 3.65 & 0.9947 & 1.00 & -1.00 & 8.15 & 1.72 & 0.9751 \\
\hline 100 & 4.68 & 13.98 & 45.64 & 0.72 & 3.53 & 0.9868 & 1.00 & 0.45 & 1.80 & 2.00 & 0.9464 \\
\hline 200 & 8.54 & 4.09 & 43.08 & 0.52 & 4.09 & 0.9940 & 1.00 & 0.63 & 1.41 & 1.70 & 0.9860 \\
\hline
\end{tabular}

${ }^{1}$ T means the treatment temperature.

\section{Conclusions}

NRG01 granite samples cored from Alxa candidate area for HLW disposal were treated by different temperatures, and then were used to carry out a series of uniaxial and tri-axial compression experiments under different confining pressures. Complete axial stress-axial strain curves and axial stress-lateral strain curves were recorded. These data were collected to study the mobilization of both Mohr-Coulomb and Hoek-Brown strength parameters during the damage and failure of NRG01 granites samples considering the effect of heat induced by the nuclear waste. According to the analyses in this study, several conclusions can be drawn as follows:

(1) Cohesion weakening and friction angle strengthening occurs during the damage and failure process of NRG01 granite samples treated by different temperatures. However, compared with the findings in the previous studies, cohesion decreases in a more gradual manner for NRG01 granite samples, and the friction angle increases immediately to its maximum value before the cohesion approaching to the residual value. This may be owing to the grain size, heterogeneity, or even the hoop effect induced by the cylindrical shape of the samples. More systematic studies are required to make clear the exact influencing factors, as well as the mechanism.

(2) The temperatures of no higher than $200{ }^{\circ} \mathrm{C}$ do not have significant influence on the characteristics of mobilized cohesion or friction angle during the damage and failure process of NRG01 granite samples. However, the samples under room temperature $\left(20^{\circ} \mathrm{C}\right)$ have higher initial cohesion than the samples treated by higher temperatures $\left(\mathrm{T}=100^{\circ} \mathrm{C}\right.$ and $\left.200^{\circ} \mathrm{C}\right)$. In addition, the samples treated by temperature of $200{ }^{\circ} \mathrm{C}$ have higher friction angle than the samples treated by lower temperatures. This should be caused by the cracks induced by the heat treatment. 
(3) The Hoek-Brown strength parameters $m_{\mathrm{b}}$ and $s$ are also observed to show non-simultaneous mobilization behaviors during the failure process of NRG01 granite samples treated by different temperatures. It is found that $m_{\mathrm{b}}$ increases significantly to a maximum value and then decreases until a residual value, and $s$ decreases gradually with the increasing plastic shear strain. The general characteristics of the mobilized $m_{\mathrm{b}}$ and $s$ are similar for NRG01 granite samples treated by different temperatures, and the fitted equations for modelling the mobilization of both parameters are proposed. The samples treated by temperature of $200{ }^{\circ} \mathrm{C}$ have higher initial $m_{\mathrm{b}}$ value, this should also be caused by the cracks induced by the heat treatment.

These findings on the mobilization of strength parameters provide a better understanding on the strength properties of NRG01 granite samples, and can be used for building a plastic constitutive model in the next step. This study should also be helpful for guiding the selection and design of HLW disposal repository in Alxa area in China. This study put forward the research on non-simultaneous mobilization of strength parameters to Hoek-Brown strength criterion, and more experimental studies are required to consolidate the results. The methods used in this paper can also be used for this kind of analyses in the other candidate areas for HLW disposal.

Author Contributions: Conceptualization, C.C.; methodology, C.C. and N.X.; formal analysis, C.C. and N.X.; investigation, C.C. and B.Z.; data curation, C.C. and B.Z.; writing-original draft preparation, C.C.; writing-review and editing, C.C.

Funding: This research was funded by Fundamental Research Funds for the Central Universities (Grant No. 2-9-2018-087); the National Natural Science Foundation of China (Grant No. 41772326); and the High-Level Radioactive Waste Disposal Project of the State Administration for Science, Technology and Industry for National Defense, China. The APC was funded by the National Natural Science Foundation of China (Grant No. 41772326).

Acknowledgments: X. Li and S. Li from Institute of Geology and Geophysics, Chinese Academy of Sciences is appreciated here for his support for this work. Y. Dong is also appreciated for his help in this study. The anonymous reviewers gave very helpful suggestions, which were valuable for improving our manuscript.

Conflicts of Interest: The authors declare no conflict of interest.

\section{References}

1. Cheng, C.; Li, X.; Li, S.; Zheng, B. Geomechanical studies on granite intrusions in alxa area for high-level radioactive waste disposal. Sustainability 2016, 8, 1329. [CrossRef]

2. Cheng, C.; Li, X.; Li, S.; Zheng, B. Failure behavior of granite affected by confinement and water pressure and its influence on the seepage behavior by laboratory experiments. Materials 2017, 10, 798. [CrossRef] [PubMed]

3. Zhao, X.G.; Wang, J.; Cai, M.; Ma, L.K.; Zong, Z.H.; Wang, X.Y.; Su, R.; Chen, W.M.; Zhao, H.G.; Chen, Q.C.; et al. In-situ stress measurements and regional stress field assessment of the Beishan Area, China. Eng. Geol. 2013, 163, 26-40. [CrossRef]

4. Zhao, X.G.; Wang, J.; Qin, X.H.; Cai, M.; Su, R.; He, J.G.; Zong, Z.H.; Ma, L.K.; Ji, R.L.; Zhang, M.; et al. In-situ stress measurements and regional stress field assessment in the Xinjiang candidate area for China's HLW disposal. Eng. Geol. 2015, 197, 42-56. [CrossRef]

5. Martin, C.D.; Read, R.S.; Martino, J.B. Observations of brittle failure around a circular test tunnel. Int. J. Rock Mech. Min. Sci. 1997, 34, 1065-1073. [CrossRef]

6. Read, R.S. 20 years of excavation response studies at AECL's underground research laboratory. Int. J. Rock Mech. Min. Sci. 2004, 41, 1251-1275. [CrossRef]

7. IAEA. Geological Disposal of Radioactive Waste: Technological Implications for Retrievability; IAEA Nuclear Energy Series No. NW-T-1.19; International Atomic Energy Agency: Vienna, Austria, 2009. Available online: http://www-pub.iaea.org/MTCD/publications/PDF/Pub1378_web.pdf (accessed on 30 September 2019).

8. Pusch, R. Geological Storage of Highly Radioactive Waste; Springer: Berlin/Heidelberg, Germany, 2009.

9. Hudson, J.A. Underground radio active waste disposal: The rock mechanics contribution. In ISRM International Symposium —6th Asian Rock Mechanics Symposium; Sharma, K.G., Ramamurthy, T., Kanjlia, V.K., Gupta, A.C., Eds.; International Society for Rock Mechanics: New Delhi, India, 2010; pp. 3-20. 
10. Wang, J. High-level radioactive waste disposal in china: Update 2010. J. Rock Mech. Geotech. Eng. 2010, 2, $1-11$.

11. Chijimatsu, M.; Nguyen, T.S.; Jing, L.; De Jonge, J.; Kohlmeier, M.; Millard, A.; Rejeb, A.; Rutqvist, J.; Souley, M.; Sugita, Y. Numerical study of the thm effects on the near-field safety of a hypothetical nuclear waste repository-bmt1 of the decovalex iii project. Part 1: Conceptualization and characterization of the problems and summary of results. Int. J. Rock Mech. Min. Sci. 2005, 42, 720-730. [CrossRef]

12. Bond, A.N.C.; Fedors, R.; Lang, P.; McDermott, C.; Neretnieks, I.; Pan, P.; Šembera, J.; Watanabe, N.; Yasuhara, H. Coupled THMC modelling of a single fracture in novaculite for DECOVALEX-2015. In Proceedings of the DFNE2014, Vancouver, BC, Canada, 19-22 October 2014.

13. Chen, L.; Wang, C.P.; Liu, J.F.; Liu, J.; Wang, J.; Jia, Y.; Shao, J.F. Damage and plastic deformation modeling of beishan granite under compressive stress conditions. Rock Mech. Rock Eng. 2015, 48, 1623-1633. [CrossRef]

14. Zhao, X.G.; Wang, J.; Chen, F.; Li, P.F.; Ma, L.K.; Xie, J.L.; Liu, Y.M. Experimental investigations on the thermal conductivity characteristics of Beishan granitic rocks for China's HLW disposal. Tectonophysics 2016, 683, 124-137. [CrossRef]

15. Zhao, X.G.; Zhao, Z.; Guo, Z.; Cai, M.; Li, X.; Li, P.F.; Chen, L.; Wang, J. Influence of thermal treatment on the thermal conductivity of Beishan granite. Rock Mech. Rock Eng. 2018, 51, 2055-2074. [CrossRef]

16. Xue, D.; Zhou, H.; Zhao, Y.; Zhang, L.; Deng, L.; Wang, X. Real-time sem observation of mesoscale failures under thermal-mechanical coupling sequences in granite. Int. J. Rock Mech. Min. Sci. 2018, 112, 35-46. [CrossRef]

17. Chen, L.; Wang, J.; Zong, Z.; Liu, J.; Su, R.; Guo, Y.; Jin, Y.; Chen, W.; Ji, R.; Zhao, H. A new rock mass classification system $Q_{H L W}$ for high-level radioactive waste disposal. Eng. Geol. 2015, 190, 33-51. [CrossRef]

18. Kim, J.-S.; Kwon, S.-K.; Sanchez, M.; Cho, G.-C. Geological storage of high level nuclear waste. KSCE J. Civ. Eng. 2011, 15, 721-737. [CrossRef]

19. Zhao, X.G.; Wang, J.; Cai, M.; Cheng, C.; Ma, L.K.; Su, R.; Zhao, F.; Li, D.J. Influence of unloading rate on the strainburst characteristics of Beishan granite under true-triaxial unloading conditions. Rock Mech. Rock Eng. 2013, 47, 467-483. [CrossRef]

20. Wang, J. On area-specific underground research laboratory for geological disposal of high-level radioactive waste in China. J. Rock Mech. Geotech. Eng. 2014, 6, 99-104. [CrossRef]

21. Marschall, P.; Giger, S.; De La Vassière, R.; Shao, H.; Leung, H.; Nussbaum, C.; Trick, T.; Lanyon, B.; Senger, R.; Lisjak, A.; et al. Hydro-mechanical evolution of the edz as transport path for radionuclides and gas: Insights from the Mont Terri rock laboratory (Switzerland). Swiss J. Geosci. 2017, 110, 173-194. [CrossRef]

22. Wang, J.; Chen, L.; Su, R.; Zhao, X. The Beishan underground research laboratory for geological disposal of high-level radioactive waste in china: Planning, site selection, site characterization and in situ tests. J. Rock Mech. Geotech. Eng. 2018, 10, 411-435. [CrossRef]

23. Alonso, E.; Alejano, L.R.; Varas, F.; Fdez-Manin, G.; Carranza-Torres, C. Ground response curves for rock masses exhibiting strain-softening behaviour. Int. J. Numer. Anal. Methods Geomech. 2003, 27, 1153-1185. [CrossRef]

24. Lee, Y.-K.; Pietruszczak, S. A new numerical procedure for elasto-plastic analysis of a circular opening excavated in a strain-softening rock mass. Tunn. Undergr. Space Technol. 2008, 23, 588-599. [CrossRef]

25. Jianxin, H.; Shucai, L.; Shuchen, L.; Lei, W. Post-peak stress-strain relationship of rock mass based on hoek-brown strength criterion. Procedia Earth Planet. Sci. 2012, 5, 289-293. [CrossRef]

26. Hajiabdolmajid, V.; Kaiser, P.K.; Martin, C.D. Modelling brittle failure of rock. Int. J. Rock Mech. Min. Sci. 2002, 39, 731-741. [CrossRef]

27. Zhao, X.G.; Cai, M. A mobilized dilation angle model for rocks. Int. J. Rock Mech. Min. Sci. 2010, 47, 368-384. [CrossRef]

28. Vermeer, P.A.; De Borst, R. Non-associated plasticity for soils, concrete and rock. HERON 1984, $29,163-196$.

29. Hajiabdolmajid, V.R. Mobilization of strength in brittle failure of rock. Géotechnique 2003, 53, 327-336. [CrossRef]

30. Guo, S.; Qi, S.; Zhan, Z.; Zheng, B. Plastic-strain-dependent strength model to simulate the cracking process of brittle rocks with an existing non-persistent joint. Eng. Geol. 2017, 231, 114-125. [CrossRef]

31. Rafiei Renani, H.; Martin, C.D. Cohesion degradation and friction mobilization in brittle failure of rocks. Int. J. Rock Mech. Min. Sci. 2018, 106, 1-13. [CrossRef] 
32. Schmertmann, J.H.; Osterberg, J.O. An Experimental Study of the Development of Cohesion and Friction with Axial Strain in Saturated Cohesive Soils; Research Conference on Shear Strength of Cohesive Soils; ASCE: Reston, VA, USA, 1960; pp. 643-694.

33. Walton, G.; Arzúa, J.; Alejano, L.R.; Diederichs, M.S. A laboratory-testing-based study on the strength, deformability, and dilatancy of carbonate rocks at low confinement. Rock Mech. Rock Eng. 2015, 48, 941-958. [CrossRef]

34. Martin, C.D. The Strength of Massive Lac du Bonnet Grantie Around Underground Openings; University of Manitoba: Winnipeg, MB, Canada, 1993.

35. Martin, C.D.; Chandler, N.A. The progressive fracture of lac du bonnet granite. Int. J. Rock Mech. Min. Sci. Geomech. Abstr. 1994, 31, 643-659. [CrossRef]

36. Hajiabdolmajid, V.R. Mobilization of Strength in Brittle Failure of Rock; Queen's University: Kingston, ON, Canada, 2001.

37. Edelbro, C. Numerical modelling of observed fallouts in hard rock masses using an instantaneous cohesion-softening friction-hardening model. Tunn. Undergr. Space Technol. 2009, 24, 398-409. [CrossRef]

38. Barton, N.; Pandey, S.K. Numerical modelling of two stoping methods in two indian mines using degradation of $\mathrm{c}$ and mobilization of $\varphi$ based on q-parameters. Int. J. Rock Mech. Min. Sci. 2011, 48, 1095-1112. [CrossRef]

39. Walton, G.; Diederichs, M.; Punkkinen, A.; Whitmore, J. Back analysis of a pillar monitoring experiment at $2.4 \mathrm{~km}$ depth in the Sudbury Basin, Canada. Int. J. Rock Mech. Min. Sci. 2016, 85, 33-51. [CrossRef]

40. Walton, G. Initial guidelines for the selection of input parameters for cohesion-weakening-friction-strengthening (CWFS) analysis of excavations in brittle rock. Tunn. Undergr. Space Technol. 2019, 84, 189-200. [CrossRef]

41. Hoek, E.; Carranza-Torres, C.; Corkum, B. Hoek-Brown failure criterion. Proc. NARMS 2002, 1, $267-273$.

42. Hoek, E.; Brown, E.T. The Hoek-Brown Failure Criterion and GSI. J. Rock Mech. Geotech. Eng. 2019, 11, 445-463. [CrossRef]

43. David, E.C.; Brantut, N.; Schubnel, A.; Zimmerman, R.W. Sliding crack model for nonlinearity and hysteresis in the uniaxial stress-strain curve of rock. Int. J. Rock Mech. Min. Sci. 2012, 52, 9-17. [CrossRef]

44. Zhao, X.G.; Cai, M.; Wang, J.; Li, P.F. Strength comparison between cylindrical and prism specimens of Beishan granite under uniaxial compression. Int. J. Rock Mech. Min. Sci. 2015, 76, 10-17. [CrossRef]

45. Song, F.; Dong, Y.-H.; Xu, Z.-F.; Zhou, P.-P.; Wang, L.-H.; Tong, S.-Q.; Duan, R.-Q. Granite microcracks: Structure and connectivity at different depths. J. Asian Earth Sci. 2016, 124, 156-168. [CrossRef]

46. Shi, X. The Tectonic Affinity of the Zongnaishan-Shalazhashan Zone in Northern Alxa and Its Implications: Evidence from Intrusive and Metamorphic Rocks. Ph.D. Thesis, Chinese Academy of Geological Sciences, Beijing, China, 2015. (In Chinese).

47. Zhou, J.; Lan, H.; Zhang, L.; Yang, D.; Song, J.; Wang, S. Novel grain-based model for simulation of brittle failure of Alxa porphyritic granite. Eng. Geol. 2019, 251, 100-114. [CrossRef]

48. Chen, L.; Liu, J.; Wang, C.; Wang, X.; Su, R.; Wang, J.; Shao, J. Elastoplastic damage model of beishan deep granite. Yanshilixue Yu Gongcheng Xuebao/Chin. J. Rock Mech. Eng. 2013, 32, 289-298.

49. Guo, R. Coupled Thermal-Mechanical Modelling of a Deep Geological Repository Using the Horizontal Tunnel Placement Method in Sedimentary Rock Using Code_Bright; Report NWMO TR-2010-22; Nuclear Waste Management Organization: Toronto, ON, Canada, 2010; p. 54. Available online: https://www.nwmo.ca/ \{\}/media/Site/Reports/2015/09/24/05/33/1695_nwmotr-2010-22horizontal-tunnelplacmentmethod_limestone_r0b_worddocument.ashx?la=en (accessed on 30 September 2019).

50. Ikonen, K. Thermal Analyses of Spent Nuclear Fuel Repository; POSIVA 2003-04; Posiva: Eurajoki, Finland, 2003; p. 61. Available online: http://www.posiva.fi/files/1018/Posiva_2003-04.pdf (accessed on 30 September 2019).

51. Rutqvist, J.; Chijimatsu, M.; Jing, L.; Millard, A.; Nguyen, T.S.; Rejeb, A.; Sugita, Y.; Tsang, C.F. A numerical study of thm effects on the near-field safety of a hypothetical nuclear waste repository-bmt1 of the decovalex iii project. Part 3: Effects of thm coupling in sparsely fractured rocks. Int. J. Rock Mech. Min. Sci. 2005, 42, 745-755. [CrossRef]

52. Weetjens, E. Update of the Near Field Temperature Evolution Calculations for Disposal of UNE-55, MOX-50 and Vitrified HLW in a Supercontainer-Based Geological Repository; SCK.CEN-ER-86; Belgian Nuclear Research Centre: Mol, Belgium, 2009; p. 14.

53. Gajewski, M.; Jemioło, S. The influence of pavement degradation caused by cyclic loading on its failure mechanisms. Balt. J. Road Bridge Eng. 2016, 11, 179-187. [CrossRef] 
54. Walton, G.; Diederichs, M.S. A new model for the dilation of brittle rocks based on laboratory compression test data with separate treatment of dilatancy mobilization and decay. Geotech. Geol. Eng. 2015, 33, 661-679. [CrossRef]

55. Walton, G.; Alejano, L.R.; Arzua, J.; Markley, T. Crack damage parameters and dilatancy of artificially jointed granite samples under triaxial compression. Rock Mech. Rock Eng. 2018, 51, 1637-1656. [CrossRef]

56. Hoek, E. Strength of jointed rock masses. Geotechnique 1983, 33, 187-223. [CrossRef]

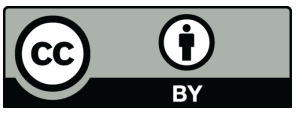

(C) 2019 by the authors. Licensee MDPI, Basel, Switzerland. This article is an open access article distributed under the terms and conditions of the Creative Commons Attribution (CC BY) license (http://creativecommons.org/licenses/by/4.0/). 